\title{
Determining the provenience of Kennewick Man skeletal remains through sedimentological analyses
}

\author{
Gary Huckleberry $^{\mathrm{a}^{*}}$, Julie K. Stein ${ }^{\mathrm{b}}$, Paul Goldberg ${ }^{\mathrm{c}}$ \\ ${ }^{a}$ Department of Anthropology, Washington State University, Pullman, WA 99164-4910, USA \\ ${ }^{\mathrm{b}}$ Department of Anthropology, University of Washington, Box 35-3100, Seattle, WA 98195-3100, USA \\ ${ }^{\mathrm{c}}$ Department of Archaeology, Boston University, 675 Commonwealth Avenue, Boston, MA 02215, USA
}

Received 28 January 2002; received in revised form 30 May 2002

\begin{abstract}
We present the results of a sedimentological study of a 9300 calendar yr old disarticulated skeleton known as Kennewick Man. Micromorphological, granulometric, mineralogical, and chemical analyses were performed on sediments from the skeleton and streambank adjacent to where the bones were found. Our results support earlier estimates that the skeleton eroded out from an $80 \mathrm{~cm}$ section of Columbia River flood deposits. Fine-textured sediments from the burial site attached to the bones indicate a low energy, fluvial depositional environment. Given the taphonomic evidence that Kennewick Man was rapidly buried, we believe that the stratigraphic and sedimentological evidence support the hypothesis that the body was interred by humans in the ground rather than being quickly buried by overbank flooding.
\end{abstract}

(C) 2003 Elsevier Science Ltd. All rights reserved.

Keywords: Sedimentology; Stratigraphy; Micromorphology; Skeleton; Columbia River

\section{Introduction}

In July 1996, a skeleton was found in shallow water along the shore of Lake Wallula in Kennewick, Washington. The skeleton eroded out of a streambank that had receded due to seasonally high water levels and wave activity. A lanceolate projectile point lodged inside the pelvis indicated that the skeleton was not recent [5]. A single radiocarbon date on bone collagen yielded a $\delta^{13} \mathrm{C}$ corrected age of $8410 \pm 60{ }^{14} \mathrm{C}$ yr BP [20] indicating that the skeleton was approximately 9300 calendar (CAL) yr old and was one of the oldest, well-preserved skeletons in the Pacific Northwest. Dubbed 'Kennewick Man' by the media, these human remains soon thereafter became the center of a complex legal, political, and scientific battle [14]. Because the skeleton was found on a 30-m long section of shoreline owned and managed by the Army Corps of Engineers (ACE), the remains fall under the jurisdiction of the American Graves and

\footnotetext{
* Corresponding author. Tel.: +1-520-792-8712; fax: +1-520-792-8795

E-mail address: ghuck@wsu.edu (G. Huckleberry).
}

Repatriation Act (NAGPRA) of 1990. A coalition of local tribes requested that the skeleton be immediately returned for reburial according to NAGPRA. ACE agreed to return the remains to local tribes, but eight scientists filed suit in federal court (Bonnichsen et al. vs. US Government) to halt repatriation so that the skeleton could be scientifically analyzed. The federal judge halted repatriation and asked the ACE to reconsider its position and clarify whether or not there was sufficient information for returning these ancient remains to the local tribes according to NAGPRA. After more than $5 \mathrm{yr}$, the case is yet to be resolved, and the skeleton meanwhile resides in a vault in the Burke Museum at the University of Washington.

In 1998, the Department of the Interior (DOI) began assisting the ACE in this case and decided that some scientific analyses would need to be performed in order to determine whether or not the skeleton was Native American and culturally affiliated with local tribes (see http://www.cr.nps.gov/aad/kennewick). In 1999, the DOI selected a scientific team to perform nondestructive analyses of the skeleton. In addition to 
morphometric and paleopathological studies, this investigation included a study of sediments adhering to the bones. Because Kennewick Man was found in a disturbed context over a $30 \mathrm{~m}$ section of shoreline, it was important to define its original burial location. Such information would help determine the geologic age of the skeleton based on geochronological information from the site [21] and provide an independent age that the DOI would use in determining Native American status.

The approach of matching the skeleton's sediments to its original burial location is based on the Locard Exchange Principle, a fundamental tenet of forensic geology that states "whenever two objects come into contact, there is always a transfer of material" $[15, p$. 7]. Although material may or may not be preserved after post-contact processes, a transfer does take place. Hence, sediment, if preserved, can be matched between two entities separated in space, and this procedure is commonly performed in solving crimes. The goal for analyzing sediments attached to Kennewick Man is to correlate them to a specific location at Columbia Park. If there is sufficient horizontal and vertical variation, i.e. anisotropy, in the physical and chemical properties of the sediments at the discovery site, then there is a good chance that a specific depth and location can be assigned to the original burial position of the skeleton.

In this paper, we present the results of sedimentological analysis of earthen materials associated with Kennewick Man. We first review the stratigraphy and geomorphology of Columbia Park previously studied by Huckleberry et al. [11] and Wakeley et al. [21]. We then present the results of micromorphological, granulometric, mineralogical, and chemical analyses of sediments adhering to the bones, and determine that these sediments are derived from the original streambank. Our investigation confirms the approximate depth from which the skeleton was exhumed and supports the radiometrically determined bone date of $9300 \mathrm{yr}$ for Kennewick Man. We are unable, however, to determine the exact burial depth due to a combination of insufficient control sampling and limited vertical variation in physical and chemical properties at the streambank. We conclude with recommendations for future studies where sediments may be used to provide important contextual information for disturbed ancient human remains.

\section{Site stratigraphy}

Stratigraphic correlation requires characterization and comparison of separate geological entities. Ideally, the best way to correlate Kennewick Man to its original burial location is to concurrently perform a complete description of the sediments adhering to the skeleton and of the site stratigraphy at Columbia Park. Unfortunately, this was not possible given that the discovery site was buried with tons of earthen debris by the ACE in April 1999 in an effort to mitigate bank erosion and site vandalism [13]. This effectively prevented us from sampling the site and forced us to rely on sediments collected during previous investigations by Huckleberry et al. [11] and Wakeley et al. [21]. Those studies were considered preliminary and limited to a noninvasive, two-dimensional analysis of the streambank at widely separated exposures. Some subsurface information was obtained along the shore through the placement of vibracores, but these were taken mainly to sample sediments beneath the streambank and thus below the original burial position of the skeleton. For our study, the lack of access to the site did not preclude us from correlating sediments, but it did limit us to using the sampling frequency of the previous study and consequently the spatial precision for defining the skeleton's provenience.

The discovery site is situated at $104 \mathrm{~m}$ above sea level on an alluvial Holocene terrace of the Columbia River located between the mouths of the Yakima and Snake rivers in the center of the Kennewick-Pasco-Richland metropolitan area (Fig. 1). This area was inundated several times during the late Pleistocene by outburst floods derived from Glacial Lake Missoula [1,2,16], which ended around $11,250{ }^{14} \mathrm{C}$ yr BP. These catastrophic events helped shape the local landscape by creating large gravel terraces and flood-scoured bedrock features. The alluvial terrace at Columbia Park is inset into Pleistocene gravel terraces formed by the outburst floods and extends several kilometers up and down the Columbia River [18].

Information on the stratigraphy of the discovery site is derived from geoarchaeological studies conducted by Huckleberry et al. [11], Wakeley et al. [21], and Chatters [5]. Although Wakeley et al. [21] subdivide the terrace into six stratigraphic units, we prefer to group the stratigraphy into two basic lithostratigraphic units. Lithostratigraphic Unit 1 is a predominantly very fine sandy surface deposit that ranges $25-80 \mathrm{~cm}$ in thickness (Fig. 2). It contains few bedforms, probably due to bioturbation and pedogenesis, and has a mineralogy dominated by quartz; many sand grains are frosted [21]. In places Unit 1 interfingers with alluvial fan deposits derived from the higher Pleistocene gravel terrace (Fig. 1). In these fan deposits and near the base of Unit 1 are discontinuous lenses of volcanic tephra chemically identified as Mount Mazama ash [21], a regional chronostratigraphic marker dated at $6700{ }^{14} \mathrm{C}$ yr BP or 7600 CAL yr BP [23]. In addition to the tephra, there are two ${ }^{14} \mathrm{C}$ dates from freshwater shell located in the lower and middle parts of Unit 1 that date $6510 \pm 60{ }^{14} \mathrm{C}$ yr BP and $6090 \pm 80{ }^{14} \mathrm{C}$ yr BP, respectively (Table 1). Soil formation in Unit 1 is characterized by a moderately organic A horizon overlying a weak cambic B horizon with Stage I calcium carbonate development. Such 


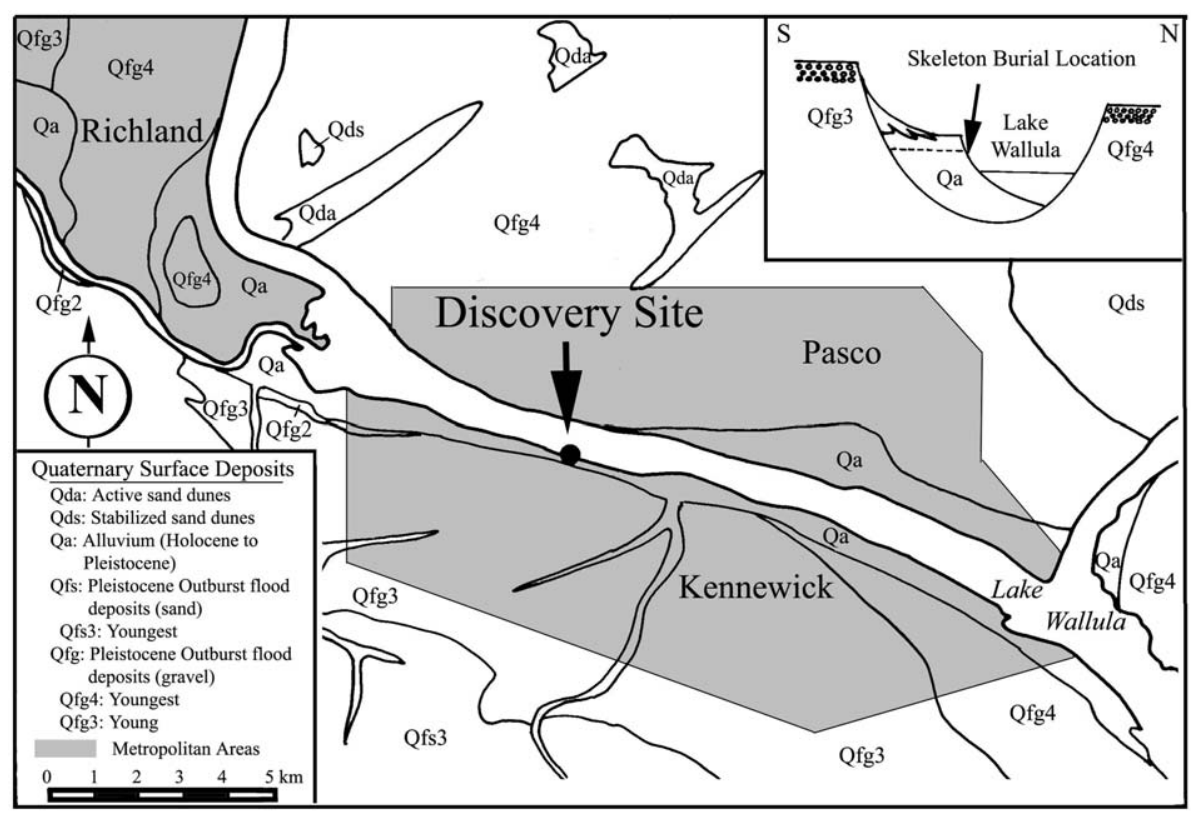

Fig. 1. Kennewick Man discovery site and surficial geology (adapted from Ref. [18]).

pedogenesis is typical for mid-Holocene soils in the Columbia Basin [24].

Lithostratigraphic Unit 2 is a weakly stratified silty alluvial deposit that displays subtle fining upward textural grading. Only the upper, approximately $60 \mathrm{~cm}$, portion of this deposit is exposed in the streambank. Although primary bedforms are preserved in places, most of the unit has been mixed and modified by bioturbation and pedogenesis. Soil formation is particularly evident in the upper $50 \mathrm{~cm}$ of the unit where there are numerous concretions of secondary calcite and silica (Stage II morphogenetic development). These same concretions are attached to the skeleton and provide an important line of evidence for correlation. Numerical age control for Unit 2 is provided by four radiocarbon dates, all based on bulk organic matter extracted from vibracore sediments (Table 1; Fig. 2). These dates range from $9010 \pm 50{ }^{14} \mathrm{C}$ yr BP at $1.2 \mathrm{~m}$ depth below ground surface to $15,330 \pm 60{ }^{14} \mathrm{C}$ yr BP at $3.1 \mathrm{~m}$ depth below ground surface. The bottom two ${ }^{14} \mathrm{C}$ ages $\left(15,330 \pm 60\right.$ and $14,560 \pm 50{ }^{14} \mathrm{C}$ yr BP) predate the last glacial outburst flood and appear to contain old carbon from some unknown source. However, the two younger vibracore dates $\left(9010 \pm 50\right.$ and $12,460 \pm 50{ }^{14} \mathrm{C}$ yr BP) appear congruent with overall site stratigraphy and soil development. Moreover, the $9010 \pm 50{ }^{14} \mathrm{C}$ yr BP date is close to the original $8410 \pm 60{ }^{14} \mathrm{C}$ yr BP date derived from the skeleton. ${ }^{1}$ The similarity in age may reflect real

\footnotetext{
Four subsequent bone collagen dates were performed by three ${ }^{14} \mathrm{C}$ laboratories (Table 1). Two of the four samples (Beta-133993 and UCR-3807) support the original date from the skeleton (see http:// www.cr.nps.gov/aad/kennewick). However, two samples (UCR-3806 and AA-34818) are significantly younger and probably contaminated by post-depositional carbon.
}

contemporaneity of deposit and skeleton, or it may be circumstantial given the shallow depth of the vibracore sample and potential for contamination of younger carbon into older sediments (Tom Stafford, 1998, personal communication to G.H.).

Texture and bedding suggest that Unit 2 is formed in a backwater area of the Columbia River, probably somewhere between the levee and flood basin zones. Although the three-dimensional architecture of the deposits is yet to be defined through excavation, Unit 2 appears to consist of a series of blanket deposits formed through overbank deposition and vertical accretion. Huckleberry et al. [11] estimate that sometime prior to the eruption of Mount Mazama $\left(6700{ }^{14} \mathrm{C}\right.$ yr BP), the Columbia River downcut into Unit 2 forming the terrace. This downcutting event is recognized elsewhere along the middle Columbia and lower Snake Rivers $[8,10,12]$ and suggests a regional climatic change, possibly increased drought and induced floodplain incision throughout much of the Columbia Basin. In contrast, Wakeley et al. [21] believe that downcutting occurred sometime after the eruption of Mount Mazama and that part of Unit 1 is alluvial in origin. Regardless of the timing of this event, deposition continued on the terrace surface, involving eolian reworking of floodplain sediments. Sedimentation eventually ceased allowing for soil formation to begin. Huckleberry et al. [11] argue that weathering of tephra and translocation of secondary calcite and silica under well-drained conditions modified the lower part of Unit 1 and upper part of Unit 2 . However, Wakeley et al. [21] postulate that most of the pedogenic alteration of Unit 2 occurred prior to the Mazama eruption. We believe that the byproducts of 


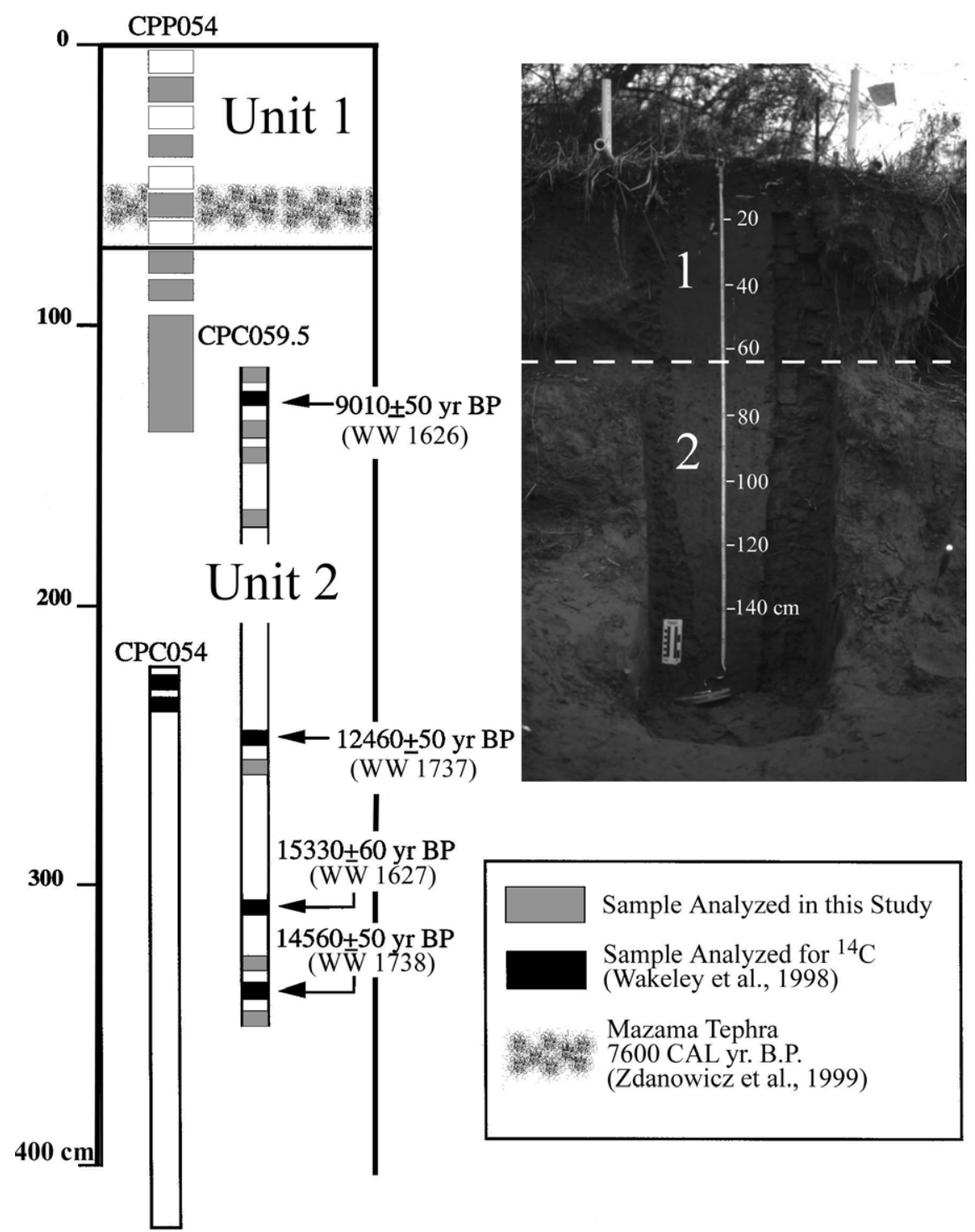

Fig. 2. Stratigraphic column with radiocarbon and sediment sample locations. Inset photo is from CPP044.

weathered tephra including secondary silica and amorphous clays like allophane identified through X-ray diffraction (XRD) analysis of Unit 2 suggest that most of the pedogenesis post-date the Mazama eruption - the largest source of volcanic glass to the soil. If it is so, then concretions of silica and calcite precipitated in the upper part of Unit 2 after $7600 \mathrm{yr}$ ago and helped cement sediment onto the bones of the skeleton.

Huckleberry et al. [11] and Wakeley et al. [21] estimated that the skeleton came from the upper part of Unit 2 (70-150 cm below the surface) somewhere in the concretion zone. Chatters [5] provided more specific estimates of $80-85$ or $135-140 \mathrm{~cm}$ for the skeleton based on similarities between the grain-size distributions of sediments from the streambank and a single sediment sample collected from the skeleton. Given the importance of determining the age of the skeleton and burial context, we attempted to test these hypotheses through more robust analysis of skeleton sediments and samples from Lithostratigraphic Units 1 and 2.

\section{Skeleton sediments}

Sediment occurs on every skeletal element of Kennewick Man including the bone exterior, marrow cavities, and interior of the cranium. Most of the exterior sediment is cemented with secondary calcite and, to a lesser degree, silica - the same cementing agents in the soil concretions. This cement prevented all of the original terrace sediment from being removed by swash and backwash as the bones laid in shallow water along the shore of Lake Wallula. Most of the calcite-indurated sediments are light gray $(2.5 \mathrm{Y} 7 / 2)$, although in places there are patches of darker $(2.5 \mathrm{Y} 5 / 2)$, more friable 
Table 1

Radiocarbon dates from the Kennewick Man skeleton (a) and discovery site (b)

(a) From Kennewick Man skeleton

\begin{tabular}{|c|c|c|c|c|c|c|c|c|}
\hline Lab no. & Skeletal element & $\begin{array}{l}\text { Museum identification } \\
\text { number }\end{array}$ & Sample no. & $\begin{array}{l}\text { Uncorrected } \\
\text { AMS }{ }^{14} \mathrm{C} \\
\text { measurement }\end{array}$ & $\begin{array}{l}\delta^{13} \mathrm{C} \\
(\mathrm{PDB})\end{array}$ & $\begin{array}{l}{ }^{13} \mathrm{C} \text {-corrected } \\
\text { measurement }\end{array}$ & $\begin{array}{l}\text { Reservoir } \\
\text { (diet)—corrected } \\
\text { age }\end{array}$ & $\begin{array}{l}\text { Calibrated date at } \\
2 \text { sigma, in CAL yr } \\
\text { BP }\end{array}$ \\
\hline Beta-133993 & $\begin{array}{l}\text { Portion of right first } \\
\text { metatarsal }\end{array}$ & $\begin{array}{l}\text { CENWW.97.R.24 } \\
\text { (MTa) }\end{array}$ & DOI 1a & $8410 \pm 40$ & -12.6 & - & - & $9510-9320$ \\
\hline UCR-3807/CAMS-60684 & $\begin{array}{l}\text { Portion of right first } \\
\text { metatarsal }\end{array}$ & $\begin{array}{l}\text { CENWW.97.R.24 } \\
\text { (MTa) }\end{array}$ & DOI $1 b$ & $8130 \pm 40^{\mathrm{a}}$ & -10.8 & - & - & - \\
\hline UCR-3476/CAMS-29578 & Fifth left metacarpal & - & APS-PS-01 & $8370 \pm 60$ & -14.9 & $8410 \pm 60$ & $7880 \pm 160$ & $8340-9200$ \\
\hline UCR-3806/CAMS-60683 & $\begin{array}{l}\text { Portion of left tibial } \\
\text { crest }\end{array}$ & CENWW.97.L.20b & $\mathrm{DOI} 2 \mathrm{~b}$ & $6940 \pm 30^{\mathrm{a}}$ & -10.3 & - & - & - \\
\hline AA-34818 & $\begin{array}{l}\text { Portion of left tibial } \\
\text { crest }\end{array}$ & CENWW.97.L.20b & DOI2a & $5750 \pm 100^{\mathrm{a}}$ & -21.9 & - & - & - \\
\hline
\end{tabular}

${ }^{\mathrm{a} C}$ Considered apparent age by laboratory and not calibrated.

(b) From discovery site

\begin{tabular}{|c|c|c|c|c|c|c|c|c|c|}
\hline Lab no. & Strat. column & Strat. unit & $\begin{array}{l}\text { Depth below } \\
\text { surface }(\mathrm{cm})\end{array}$ & Material dated & $\begin{array}{l}\text { Uncorrected } \\
\text { AMS }{ }^{14} \mathrm{C} \\
\text { measurement }\end{array}$ & $\delta^{13} \mathrm{C}(\mathrm{PDB})$ & $\begin{array}{l}{ }^{13} \mathrm{C} \text {-corrected } \\
\text { measurement }\end{array}$ & $\begin{array}{l}\text { Reservoir } \\
\text { (diet)—corrected age }\end{array}$ & $\begin{array}{l}\text { Calibrated date at } \\
2 \text { sigma, in CAL yr } \\
\text { BP }\end{array}$ \\
\hline Beta-113838 & СРP005 & 1 & $60-80$ & Total shell carbonate & $6230 \pm 60$ & -8.2 & $6510 \pm 60$ & - & $7470-7255$ \\
\hline Beta-113977 & СРP005 & 1 & $60-65$ & Total shell carbonate & $5820 \pm 80$ & -8.3 & $6090 \pm 80$ & - & $7180-6755$ \\
\hline WW 1626 & СРC 059.5 & 2 & $10-20$ & Bulk sediment organic carbon & $9010 \pm 50^{\mathrm{b}}$ & $-25^{\mathrm{c}}$ & - & - & - \\
\hline WW 1737 & СРC 059.5 & 2 & $130-138$ & Bulk sediment organic carbon & $12460 \pm 50^{\mathrm{b}}$ & $-25^{\mathrm{c}}$ & - & - & - \\
\hline WW 1627 & СРC 059.5 & 2 & 190-200 & Bulk sediment organic carbon & $15330 \pm 60^{\mathrm{b}}$ & $-25^{\mathrm{c}}$ & - & - & - \\
\hline WW 1738 & СРC 059.5 & 2 & $220-229$ & Bulk sediment organic carbon & $14560 \pm 50^{\mathrm{b}}$ & $-25^{\mathrm{c}}$ & - & - & - \\
\hline
\end{tabular}

The youngest two ${ }^{14} \mathrm{C}$ ages from the skeleton are considered apparent ages affected by younger carbon. Sources: Refs. [20,21] and DOI website (http://www.cr.nps.gov/aad/kennewick).

${ }^{\mathrm{b}}$ Mean residence age and not calibrated.

${ }^{\mathrm{c}}{ }^{13} \mathrm{C}$ numbers with no decimal place are estimated values. Those given to 0.1 are measured directly on the gas used for the ${ }^{14} \mathrm{C}$ measurement. 
sediment. We expected that fine-textured beach sediment might also be attached to the skeleton, and hypothesized that the darker, more friable sediment was derived from the shore zone after the skeleton was exhumed by wave activity. We consequently sampled both dark and light sediments for analysis.

\section{Laboratory methods}

We selected sediments from the skeleton where enough sediment could be retrieved for laboratory analysis without the risk of damaging the cortex of the bone (see Huckleberry and Stein, 1999). Because most of the skeleton sediment was firmly cemented, we used a Dremel drill with different shaped steel, carbide steel, and diamond-tipped bits. The resistance of the cemented sediment to drilling was surprisingly strong; drill bits were frequently worn and replaced. Those sediments that required extended drilling for extraction were omitted from particle-size analysis given the potential for alteration of grain sizes. The largest amounts of sediment were retrieved from inside the cranium where sediments were friable enough that we could extract intact peds approximately $1 \mathrm{~cm}$ in diameter. A total of 36 sediment samples were collected from various locations on the skeleton (Fig. 3; Table 2) and placed in separate plastic vials for laboratory analysis.

Bulk sediment samples from the site were provided by the ACE Waterways Experiment Station in Vicksburg, MS. During the previous geoarchaeological study, a transect was established along the shore to provide spatial reference. The skeleton was recovered in a zone of shallow water between CPP057 and CPP093 [5]. Unfortunately, no control sediments are available from this segment, and we thus elected to use sediment samples collected from a position as close to this segment as possible - stratigraphic column CPP054 (Fig. 2), located approximately $3 \mathrm{~m}$ downstream to the east from where the skeleton was recovered. We also used sediments from vibracores collected by WES (stored at the Department of Anthropology, Washington State University). Six sediment samples are from vibracore CPC059.5, which was placed along the shore at the foot of the streamcut, $5.5 \mathrm{~m}$ west of CPP054. We also collected two samples of modern shore deposits from the top of vibracore CPC054 and a calcite concretion from vibracore CPC060, resulting in a total of 17 control sediment samples from the site (Table 2).

Our goal was to identify physical and chemical signatures in the sediments that could be used to match skeleton sediments to a specific depth at the site. We submitted sediments to different laboratories for micromorphological, granulometric, XRD, thermogravimetric, and trace-element analyses (Table 2; see [25] for details on pretreatment and analysis). The traceelement chemistry of sediments from the site and

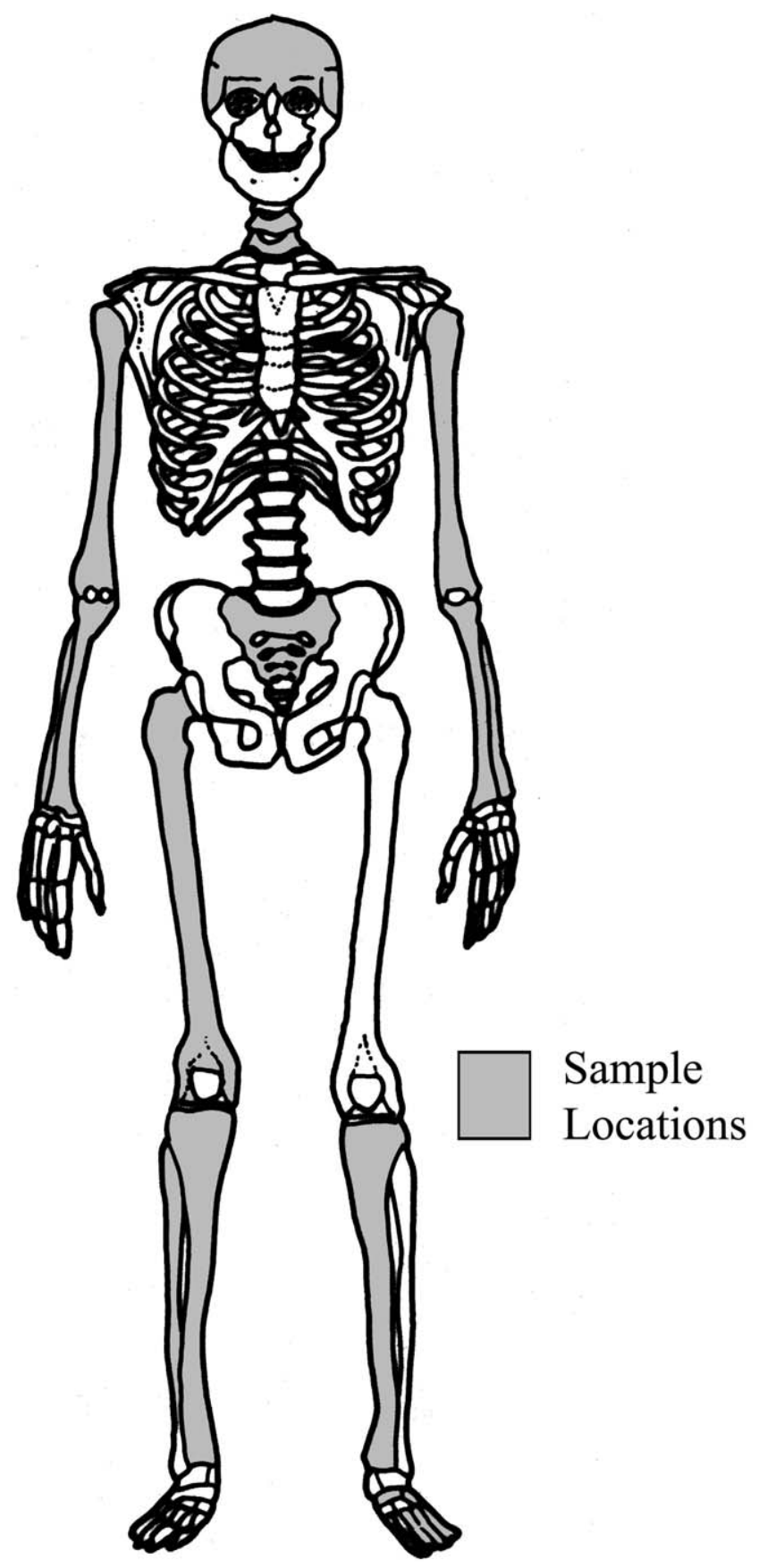

Fig. 3. Skeletal elements sampled for sediment extraction.

skeleton (Appendix A) were relatively uniform and provided little insight into the original location of the skeleton. Hence, we focus here on the other four analyses performed.

\subsection{Thin-section and micromorphology analysis}

Soil peds from the site and cranium of the skeleton were thin-sectioned at the Pedology and Quaternary Studies Laboratory, Washington State University. Each 
Table 2

Inventory of skeletal and site sediments selected for laboratory analyses

\begin{tabular}{|c|c|c|c|c|c|}
\hline Sample & PSA & XRD & TGA & $\mathrm{TE}$ & TS \\
\hline Cranium (U.1.a); ped & & & & & $\mathrm{X}$ \\
\hline Cranium (U.1.a); sediment & $\mathrm{X}$ & $\mathrm{X}$ & $\mathrm{X}$ & $\mathrm{X}$ & \\
\hline Left arm (L.20c+L.15b+L.15a) & $\mathrm{X}$ & & & & \\
\hline $\begin{array}{l}\text { Right arm+sacrum+ pelvis } \\
(\text { R.13b+U.7b+A.I.17a) }\end{array}$ & & & & $\mathrm{X}$ & \\
\hline Cervical vertebrae (A.U4(C5a)) & $\mathrm{X}$ & & & & \\
\hline Pelvis (A.I.17a); dark sediment & & $\mathrm{X}$ & & $\mathrm{X}$ & \\
\hline Left metatarsals (L.24(Mta+Mtb)) & $\mathrm{X}$ & $\mathrm{X}$ & $\mathrm{X}$ & $\mathrm{X}$ & \\
\hline Right fibula (R.21a) & $\mathrm{X}$ & & & & \\
\hline Right femur; R.18a; marrow cavity & & $\mathrm{X}$ & $\mathrm{X}$ & $\mathrm{X}$ & \\
\hline $\begin{array}{l}\text { Unidentified (I.25.C; } \\
\text { exterior concretion) }\end{array}$ & & $\mathrm{X}$ & $\mathrm{X}$ & $\mathrm{X}$ & \\
\hline CPP $054,10-20 \mathrm{~cm}$ & $\mathrm{X}$ & $\mathrm{X}$ & $\mathrm{X}$ & $\mathrm{X}$ & \\
\hline CPP054, 30-40 cm & $\mathrm{X}$ & $\mathrm{X}$ & $\mathrm{X}$ & $\mathrm{X}$ & \\
\hline $\mathrm{CPP} 054,50-60 \mathrm{~cm}$ & $\mathrm{X}$ & $\mathrm{X}$ & $\mathrm{X}$ & $\mathrm{X}$ & \\
\hline CPP054, 70-80 cm & $\mathrm{X}$ & $\mathrm{X}$ & $\mathrm{X}$ & $\mathrm{X}$ & \\
\hline CPP054, 80-90 cm & $\mathrm{X}$ & $\mathrm{X}$ & & $\mathrm{X}$ & \\
\hline CPP054, 80-90 cm; concretion & & & $\mathrm{X}$ & & \\
\hline CPP054, 95-135 cm & $\mathrm{X}$ & $\mathrm{X}$ & $\mathrm{X}$ & $\mathrm{X}$ & \\
\hline СРC $059.5,0-10 \mathrm{~cm}$ & $\mathrm{X}$ & $\mathrm{X}$ & $\mathrm{X}$ & $\mathrm{X}$ & \\
\hline СРC $059.5,30-40 \mathrm{~cm}$ & $\mathrm{X}$ & $\mathrm{X}$ & $\mathrm{X}$ & $\mathrm{X}$ & \\
\hline $\mathrm{CPC} 059.5,60-66 \mathrm{~cm}$ & $\mathrm{X}$ & $\mathrm{X}$ & $\mathrm{X}$ & $\mathrm{X}$ & \\
\hline СРC059.5, $138-150 \mathrm{~cm}$ & $\mathrm{X}$ & & & & \\
\hline CPC059.5, $210-220 \mathrm{~cm}$ & $\mathrm{X}$ & & & & \\
\hline СРC059.5, 229-237 cm & $\mathrm{X}$ & & & & \\
\hline $\mathrm{CPC} 054,0-5 \mathrm{~cm}$ & $\mathrm{X}$ & & & & \\
\hline $\mathrm{CPC} 054,5-10 \mathrm{~cm}$ & $\mathrm{X}$ & & & & \\
\hline СРC059.5, 25-30 cm & $\mathrm{X}$ & & & & \\
\hline CPC060, 0-10 cm; concretion & & & & $\mathrm{X}$ & \\
\hline
\end{tabular}

PSA, particle-size analysis; XRD, X-ray diffraction; TGA, thermogravimetric analysis; TE, trace element analysis; TS, thin-section analysis.

sample was impregnated with epoxy, ground to a thickness of $30 \mu \mathrm{m}$, and mounted on glass slides. Thin sections included small $(28 \times 46 \mathrm{~mm})$ and large formats $(50 \times 100 \mathrm{~mm})$ and were analyzed using polarized light microscopy at magnifications ranging from 20 to $200 \times$. Descriptive terminology follows that of Bullock et al. [3] and Courty et al. [9].

\subsection{Granulometry}

Given the small $(<1 \mathrm{~g})$ sample sizes, grain size distributions were determined with optical laser diffraction using a Malvern Mastersizer ${ }^{\mathrm{rm}}$ at the Pedology and Quaternary Studies Laboratory, Washington State University. Sediment samples were disaggregated and pretreated with dilute acid (NaOAc) to remove carbonates, and then dispersed with sodium hexametaphosphate.

\subsection{X-ray diffraction}

Standard powder XRD techniques were performed using a Phillips PW 1830 X-ray generator at the
Department of Materials Science and Engineering Laboratory at the University of Washington. Each sample was ground in an agate mortar, placed within a sample holder, and irradiated for $1 \mathrm{~h}$ and $13 \mathrm{~min}$ at theta $4-70^{\circ}$. The XRD intensities were determined from the observed peak heights following background subtraction using the X-ray powder diffraction pattern processing code JADE 2.1 and 3.1 (Materials Data, Inc., Livermore, CA).

\subsection{Thermogravimetry}

Thermogravimetric analysis was performed on bulk, untreated, but air-dried samples in both a standard furnace at the University of Washington Geoarchaeology Laboratory and a Perkin Elmer 7 Series/Unix TGA7 Thermogravimetric Analyzer (TGA) located in the Thermal Analysis Laboratory at the Department of Materials Science and Engineering, University of Washington.

\section{Results}

\subsection{Micromorphology}

The micromorphological analysis of a ped removed from the cranium was compared in a blind test to that of thin sections of soil peds collected from the streambank by Huckleberry et al. [11]. Thin sections from Units 1 and 2 are from CPP044, СРP093, and CPP303. Micromorphological observations of texture and fabric of samples from Units 1 and 2 are compatible with an alluvial setting dominated by reworked loess subjected to soil formation including some decalcification (Fig. 4). Clastic components are dominated with silt-sized grains of quartz and some heavy minerals, all within a calcareous matrix. The proportions do vary from sample to sample (see photomicrographs, Fig. 4), but this is to be expected in water-deposited sediments. Sediment within the cranium is also composed of similar silt-sized calcareous components that have been modified by soil formation. The compositional and textural similarity of the cranial and fluvial sediments indicates that the cranium is filled with sediment derived from the burial site and was not introduced along the shore after the skeleton was exhumed. However, there is an inadequate differentiation of the fabric and mineralogy to pinpoint from exactly which stratum the cranium sediment was derived.

\subsection{Granulometry}

We submitted 20 sediment samples for granulometric analysis; 15 from the site and five from the skeleton 

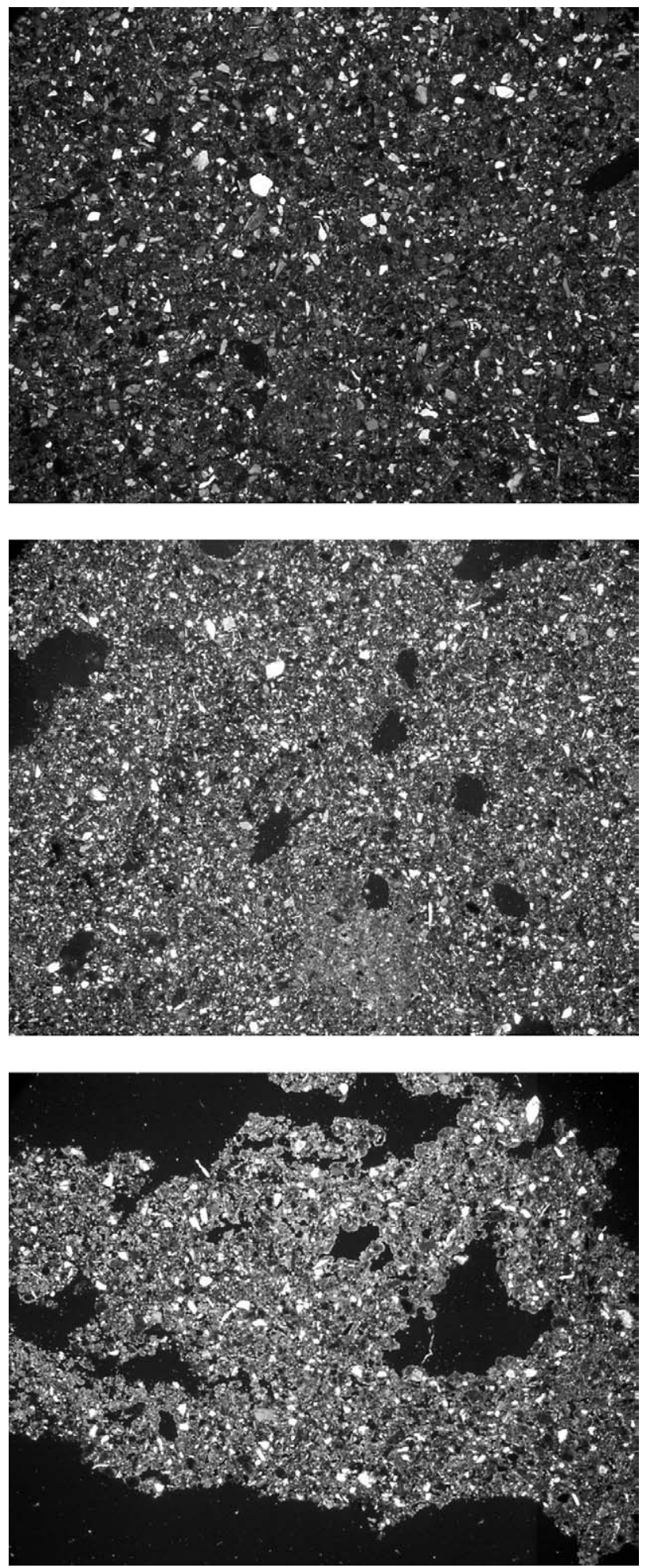

Fig. 4. Thin sections of sediment from Unit 1 at CPP044, $65-70 \mathrm{~cm}$ depth (a), Unit 2 at CPP093, 85-90 cm depth (b), and cranium (c). Unit 1 sample reveals quartz silt and fine sand in a calcareous matrix. Unit 2 sample has similar quartz and calcite content, but note circular voids and incipient carbonate concentrations in the lower part of the photograph. Some localized impregnations of iron/manganese are found in the left hand part of the photograph. Cranium sample likewise is dominated by quartz silt and interstitial fine-grained carbonate. All photographs in cross-polarized light with width view of approximately $3.1 \mathrm{~mm}$.
(Table 3). In order to increase sample number, we included granulometric data from sediment samples collected by Chatters [5] adjacent to the skeleton discovery site. These samples were analyzed in the same laboratory using the same procedures and instrument $\left(\right.$ Mastersizer $\left.^{\text {TMI }}\right)$. The grain-size distributions are presented as semilog relative frequency curves (Fig. 5) with measures of volume-weighted mean diameter and span, the latter defined as the width of distribution $\left(D_{90}-\right.$ $\left.\left.D_{10}\right) / D_{50}\right)$. We performed repeated measurements on several samples in order to assess reproducibility (see Huckleberry and Stein, 1999). The range in particle-size means for all repeat runs on the same sample is $\leq 11 \mu \mathrm{m}$ except for one sample (CPC059.5, 0-10 cm) that had a difference of $23 \mu \mathrm{m}$. Inherent measuring error is due to both variation in subsampling and the sediment:water flux across the laser beam [4].

The analyses indicate that both skeleton and site sediments have little variation in grain size and sorting (Fig. 5; Table 3). Particle-size means for Units $1(n=6)$ and $2(n=18)$ range from 55 to $79 \mu \mathrm{m}$ and from 42 to $82 \mu \mathrm{m}$, respectively. The degree of spread of the distribution (span) varies 2.4-4.1 for Unit 1, and 2.3-3.4 for Unit 2. Both $t$ and $F$ tests indicate that there is no statistical difference at a $95 \%$ confidence interval between Units 1 and 2 in terms of mean particle size or span. This precludes any correlation of skeleton sediments to any specific depth in either Unit 1 or 2 based solely on grain size.

Like the streambank sediments, the skeleton sediments $(n=5)$ vary little in their grain-size distributions (Fig. 5). Mean particle size ranges from 64 to $84 \mu \mathrm{m}$; particle size span ranges from 2.5 to 3.0. These sediments are slightly coarser than the single skeleton sediment sample analyzed by Chatters [5] (Table 1) that varied from 56 to $64 \mu \mathrm{m}$ with three repeated runs. Given the inherent measuring error in the laser diffraction method, the difference is not significant. Likewise, the mean particle size and span values for skeleton sediments are equivalent to several samples in Units 1 and 2, and prevent us from designating a specific burial depth. At best, we can recognize a different origin for the darker sediment located on the pelvis. This sediment is slightly coarser than the lighter sediment and falls outside the confidence intervals of samples from both Units 1 and 2, suggesting that it was deposited after the skeleton was eroded from the bank.

In summary, we cannot reject Unit 1 or 2 as sources for the skeleton based on granulometry of the deposits and sediments adhering to the bones. Both deposits contain overbank alluvium and wind-reworked alluvium that are similar in texture and sorting. Any previous textural breaks due to bedded alluvium in Unit 2 have been all but effaced by soil formation and bioturbation. This mixing limits our ability to use texture for correlating the skeleton to the site. 
Table 3

Granulometric statistics

(a) For sediments from discovery site including Chatters' [5] data

\begin{tabular}{|c|c|c|c|c|c|}
\hline Location & Depth $(\mathrm{cm})$ & Stratum & Lab no. & Mean $(\mu \mathrm{m})$ & Span \\
\hline СРP054 & $10-20$ & 1 & $6(2)$ & 68 & 4.1 \\
\hline CPP054 & $30-40$ & 1 & 13 & 79 & 2.7 \\
\hline СРP054 & $50-60$ & 1 & 7 & 55 & 2.4 \\
\hline Chatters & $20-30$ & 1 & A & 59 & 2.8 \\
\hline Chatters & $40-50$ & 1 & B & 76 & 2.8 \\
\hline Chatters & $60-65$ & 1 & $\mathrm{C}$ & 77 & 2.8 \\
\hline СРP054 & $70-80$ & 2 & $8 \mathrm{Rb}$ & 55 & 3.0 \\
\hline CPP054 & $80-90$ & 2 & 9 & 68 & 2.5 \\
\hline СРР054 & $95-135$ & 2 & 10 & 47 & 2.7 \\
\hline СРC59.5 & $0-10$ & 2 & $11 \mathrm{a}$ & 60 & 2.8 \\
\hline СРС 59.5 & $25-30$ & 2 & 20 & 51 & 2.9 \\
\hline СРC59.5 & $30-40$ & 2 & $12 \mathrm{a}$ & 51 & 3.1 \\
\hline СРC59.5 & $60-66$ & 2 & 14 & 82 & 2.3 \\
\hline Chatters & $70-75$ & 2 & $\mathrm{E}$ & 52 & 3.4 \\
\hline Chatters & $80-85$ & 2 & $\mathrm{D}$ & 57 & 3.3 \\
\hline Chatters & $95-100$ & 2 & $\mathrm{~F}$ & 47 & 3.4 \\
\hline Chatters & $105-110$ & 2 & G & 48 & 3.0 \\
\hline Chatters & $115-120$ & 2 & $\mathrm{H}$ & 68 & 2.6 \\
\hline Chatters & $125-130$ & 2 & I & 62 & 3.0 \\
\hline Chatters & $135-140$ & 2 & $\mathrm{~J}$ & 59 & 3.1 \\
\hline Chatters & $145-150$ & 2 & $\mathrm{~K}$ & 52 & 3.2 \\
\hline Chatters & $155-160$ & 2 & $\mathrm{~L}$ & 54 & 3.3 \\
\hline Chatters & $165-170$ & 2 & M & 48 & 3.3 \\
\hline Chatters & $175-180$ & 2 & $\mathrm{~N}$ & 42 & 3.1 \\
\hline
\end{tabular}

(b) For the skeleton sediment

\begin{tabular}{|c|c|c|c|c|c|}
\hline Location & Skeletal element & Material & Lab no. & Mean $(\mu \mathrm{m})$ & Span \\
\hline Left arm & L. $20 c+$ L. $15 b+L .15 a$ & Concretion & $1 \mathrm{a}$ & 63 & 2.8 \\
\hline Cervical vertebrae & A.U4(C5a) & Sediment & $2 \mathrm{a}$ & 70 & 2.6 \\
\hline Left foot & L.24(Mta+Mtb) & Sediment & $3 a$ & 72 & 3.0 \\
\hline Right leg & R.21a & Dark sediment & 4 & 84 & 2.5 \\
\hline Cranium & U.1.a & Friable ped & $5 \mathrm{a}$ & 78 & 2.5 \\
\hline
\end{tabular}

(c) For both site and skeleton

\begin{tabular}{lrlll}
\hline & $n$ & Mean $(\mu \mathrm{m})$ & Standard deviation & Coefficient of variation \\
\hline Unit 1 particle size mean & 6 & 69.2 & 10.2 & 0.15 \\
Unit 2 particle size mean & 18 & 55.7 & 9.7 & 0.17 \\
Skeleton particle size mean & 5 & 73.4 & 7.8 & 0.11 \\
Unit 1 uniformity & 6 & 0.92 & 0.19 & 0.21 \\
Unit 2 uniformity & 18 & 0.93 & 0.11 & 0.11 \\
Skeleton uniformity & 5 & 0.82 & 0.07 & 0.08 \\
Unit 1 span & 6 & 2.95 & 0.61 & 0.21 \\
Unit 2 span & 18 & 3.01 & 0.32 & 0.11 \\
Skeleton span & 5 & 2.68 & 0.22 & 0.08 \\
\hline
\end{tabular}

Depths for CPP054 and Chatters' profile are measured from surface; depths for CPC59.5 are measured from top of core.

\subsection{X-ray diffraction}

XRD was performed in order to distinguish the mineralogical differences at depth. Given that both Units 1 and 2 contain sediments derived from the Columbia River, the overall mineral assemblages do not change substantially with depth. Quartz dominates all the samples, and most of the mineralogical differences are small and associated with carbonate minerals (e.g. calcite and ankerite), especially in sediments cemented onto the bone, and minor crystalline minerals. Because we could not distinguish different samples on mineral assemblages alone, we focused on qualitative comparison of the XRD plots of minor mineral peaks. For example, the skeleton sediment XRD plots (curves 5-7 in Fig. 6) best match sediment from the streambank at 

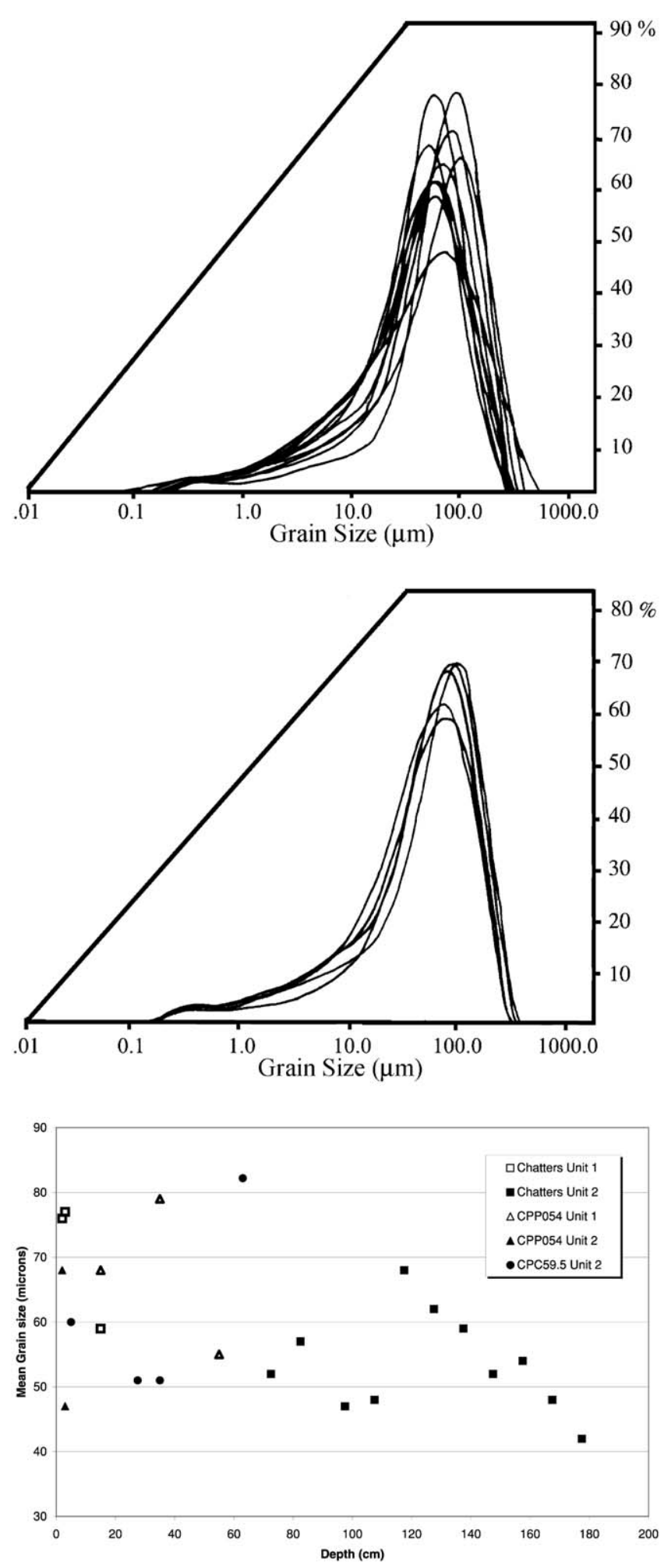

Fig. 5. Particle-size relative frequency curves for site (a) and skeleton (b) sediments, and mean grain-size vertical distribution at discovery site (c).
$70-80 \mathrm{~cm}$ depth (curve 2), and to a lesser degree, 95$135 \mathrm{~cm}$ depth (curve 4). This can be demonstrated by comparing the plots at points A-C in Fig. 6. At point A, the skeleton samples have a single feldspar peak that best matches samples from 30 to 40,70 to 80 , and 95 to $135 \mathrm{~cm}$ depth. However, a double silica peak at point B for the $30-40 \mathrm{~cm}$ sample does not match the skeleton samples and is thus an unlikely match. At point $\mathrm{C}$, the match is somewhat better for sediments from 70 to $80 \mathrm{~cm}$ depth because most of the skeleton samples have a pronounced silica double peak whereas it is diminished in the $95-135 \mathrm{~cm}$ sample. Although not conclusive, the XRD data suggest that skeleton sediments are mineralogically most similar to sediments located in the upper part of Unit 2 at $70-80 \mathrm{~cm}$ depth.

\subsection{Thermogravimetry}

Units 1 and 2 are enriched in organic matter and calcium carbonate at various depths.

Thermogravimetric analysis was used to measure slight variations in organic matter and calcium carbonate content at depth. A simple form of thermogravimetry is loss-on-ignition whereby samples are heated and reweighed at 550 and $1000{ }^{\circ} \mathrm{C}$ yielding the percentage by weight of organic matter and calcium carbonate, respectively. We selected five sediment samples from the skeleton and nine from the discovery site for analysis (Table 2).

Sediments from the upper part of Unit 1 contain the highest organic matter content due to humification on the surface, A horizon (Table 4). Only the dark sediment from the pelvis matches these deposits in terms of organic matter content, but granulometric data suggest that this sediment has a different source associated with the shoreline. The remaining samples have similar amounts of organic matter, which may be both pedogenic, i.e. due to humification, and depositional in origin [19]. Calcium carbonate content varies with depth and is maximum in the upper part of Unit 2 where the concretions are best developed. One of the best matches in calcium carbonate content is between the concretion from CPP054, 80-90 cm (49\%) and a concretion removed from the skeleton $(52 \%)$.

In addition to simple loss-on-ignition, we used a TGA to record continuous measurements of weight loss as organic matter and carbonate were heated and oxidized. This allowed for a more detailed comparison of sediment samples. TGA results were plotted as weight-loss and derivative (i.e. rate of weight loss) curves by the Perkins Elmer 7 Series/Unix TGA 7 software (Fig. 7). There are three temperature ranges of major weight loss. One is between 100 and $200{ }^{\circ} \mathrm{C}$ when water is volatilized from organic matter and clay lattices. Another is between 400 and $600{ }^{\circ} \mathrm{C}$ when soil organic matter oxidizes. 


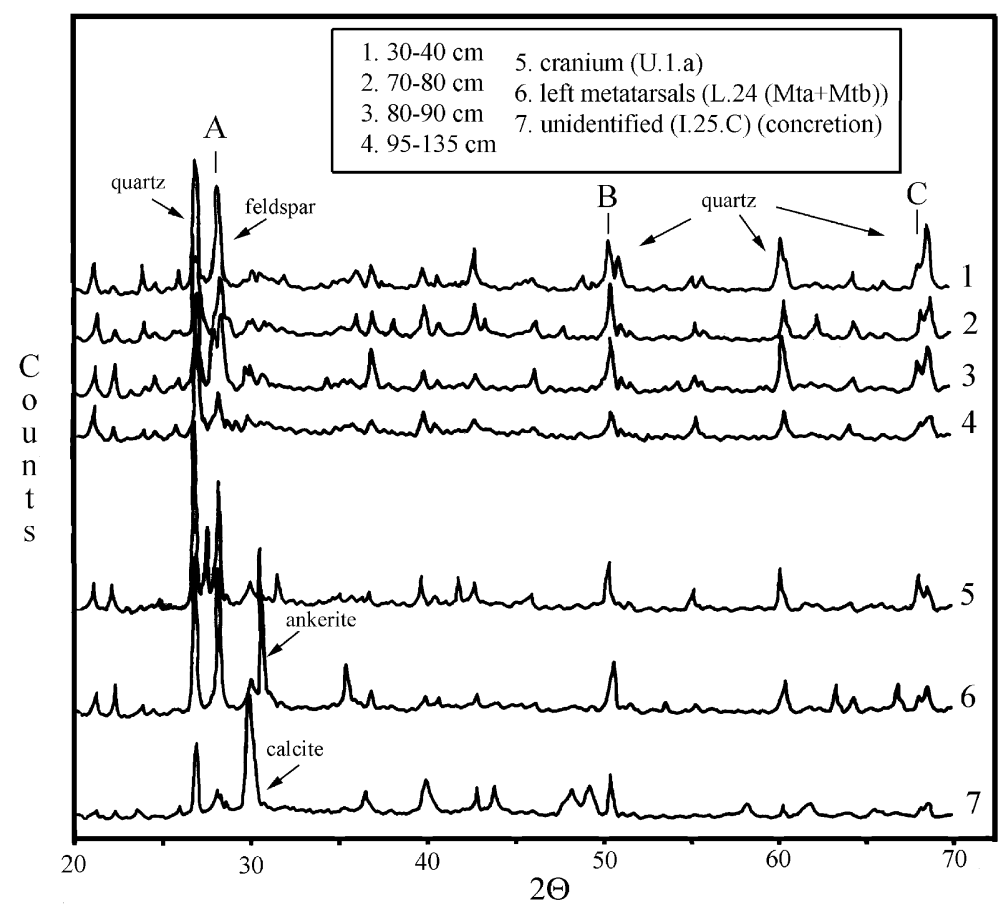

Fig. 6. XRD charts for selected site and skeleton sediments.

Table 4

Loss-on-ignition organic matter and calcium carbonate content of sediments

(a) From Columbia Park

\begin{tabular}{llllr}
\hline Location & Depth $(\mathrm{cm})$ & Stratum & Organic matter $(\%)$ & $\mathrm{CaCO}_{3}(\%)$ \\
\hline CPP054 & $10-20$ & 1 & 2.2 & 2.8 \\
CPP054 & $30-40$ & 1 & 2.1 & 4.5 \\
CPP054 & $50-60$ & 1 & 1.7 & 6.7 \\
CPP054 & $70-80$ & 2 & 1.5 & 8.7 \\
CPP054 & $80-90$ & 2 & 1.0 & 4.7 \\
CPP054 & $95-135$ & 2 & 1.8 & 5.0 \\
CPC059.5 & $0-10$ & 2 & 1.6 & 35.0 \\
CPC059.5 & $30-40$ & 2 & 1.7 & 1.8 \\
CPC059.5 & $60-66$ & 2 & & 1.8 \\
\hline
\end{tabular}

\section{(b) From skeleton}

\begin{tabular}{|c|c|c|c|c|}
\hline Location & Element & Material & Organic matter (\%) & $\mathrm{CaCO}_{3}(\%)$ \\
\hline Ox coxea-left & 97A.I.17a & Dark sediment & 2.3 & 3.7 \\
\hline Metatarsals-left & 97.L.24 (Mta+Mtb) & Concretion & 1.8 & 18.5 \\
\hline Cranium & 97.U.1a & Sediment & 1.2 & 6.7 \\
\hline Unidentifiable fragment & 97.I.25c & Concretion & 1.2 & 51.5 \\
\hline Femur-right & 97.R.18a & Sediment & 1.3 & 18.4 \\
\hline
\end{tabular}

The third period of weight loss is the largest and located between 600 and $800{ }^{\circ} \mathrm{C}$ when calcium carbonate is oxidized.

No two sediment curves are identical but some curves are more similar than others. For example, as expected, samples from the upper part of Unit 1 (curves 1 and 2 in Fig. 7) have a multimodal plot displaying more prominent water loss and oxidation of organic matter. Samples from lower part in the profile (curves 3 through 6) have a more unimodal plot reflecting the predominance of calcium carbonate oxidation. There is a trend of deeper samples from the streamcut having maximum 


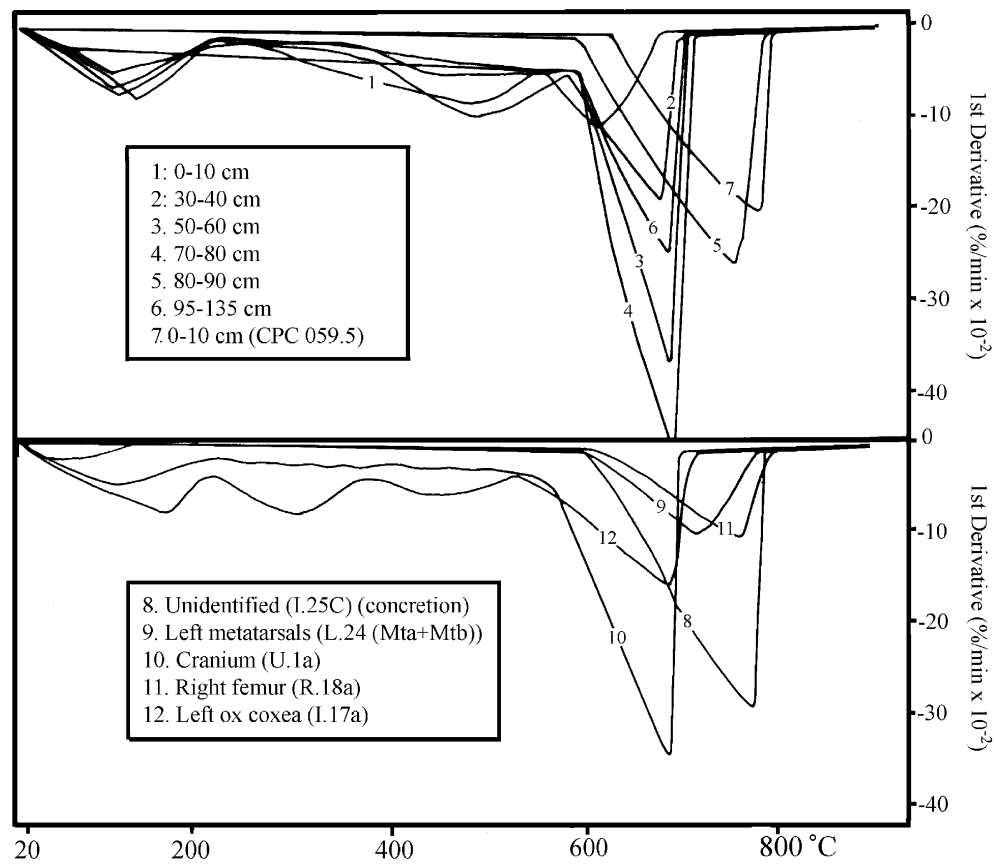

Fig. 7. TGA weight loss derivative curves for selected site and skeleton sediments.

weight loss rates at higher temperatures, but the cause of this trend is unclear. The skeleton samples (curves 8 through 12) have similar TGA curves but vary slightly in their temperature of maximum weight loss. Sediment from the cranium (curve 10) best matches samples from 50 to 60 (curve 3) and from 70 to $80 \mathrm{~cm}$ (curve 4), whereas the concretion from the unidentified bone fragment (curve 8) best matches 80-90 (curve 5) and $0-10 \mathrm{~cm}$ in vibracore CPC059.5 (curve 7) where concretions are well developed in the soil. We are unable to assign a precise depth for the skeleton based on the TGA curves because of the multiple overlap between different samples, but collectively the TGA curves and loss-onignition values support the hypothesis that the skeleton is derived from the concretion zone in the upper part of Unit 2.

\section{Discussion and conclusions}

The Locard Exchange Principle was validated in our analysis of the skeleton and site sediments. Despite erosion and localized transport along the shore of Lake Wallula, Kennewick Man still retains sediment from his original burial site. This sediment is cemented mostly by calcite and matches deposits located within the upper part of Lithostratigraphic Unit 2 at Columbia Park. Except for dark sediments loosely adhering to the pelvis, texture, mineralogy, and calcium carbonate content of the skeleton sediments, all are compatible with sediments located in the upper portion of Unit 2 (approxi- mately $60-140 \mathrm{~cm}$ depth). The dark sediments have higher organic matter content and appear to be associated with the shoreline; they were emplaced after the skeleton was eroded from the streambank and reworked in shallow water.

Precision in determining burial depth is limited by sedimentological isotropy due to post-depositional mixing of the originally stratified deposits. Bioturbation and soil formation have homogenized much of the stratigraphy within each lithostratigraphic unit. Inadequate vertical variation in the physical and chemical properties of sediments in the upper part of Unit 2 precludes ascribing a more specific depth to the skeleton. Chatters [5] hypothesizes that the skeleton was derived from either $80-85$ or $135-140 \mathrm{~cm}$ based on similar particle-size curves for streambank and skeleton sediments. We cannot nullify this hypothesis, but we find that the differences in grain-size distributions between streambank and skeleton sediments are not statistically different. Hence, we cannot assign any depth to the skeleton based on granulometry alone. Our estimate of burial depth $(60-140 \mathrm{~cm})$ is based on similarity of combined properties including granulometry, mineralogy, and carbonate content.

The age of the upper part of Unit 2 is compatible with the ${ }^{14} \mathrm{C}$ dates for the skeleton. Organics extracted from a bulk sediment sample collected at $10-20 \mathrm{~cm}$ in vibracore CPC059.5 yielded a conventional date of $9010 \pm 50{ }^{14} \mathrm{C}$ yr BP (WW-1626) [21] (Fig. 2; Table 1). This sample corresponds to approximately $120 \mathrm{~cm}$ depth below the surface, or the lower part of the zone that most likely 
contained the skeleton $(60-140 \mathrm{~cm}$ depth). Although ages derived from bulk organics should be interpreted as apparent mean ages for the associated stratum, the ${ }^{14} \mathrm{C}$ date from the core is similar to the original $8370 \pm 60$ ${ }^{14} \mathrm{C}$ yr BP bone collagen date from the skeleton. The geological evidence is not inconsistent with the approximately 9000 CAL yr age for Kennewick Man.

One question that remains unanswered is whether or not Kennewick Man was interred or buried by natural processes. The taphonomic evidence - a relatively complete and well preserved skeleton with little to no sign of carnivore activity - indicates rapid burial. Human remains left at the surface for any length of time normally have significant post-mortem alterations including carnivore teeth marks and absence of small bones. Chatters [5,6] favors a scenario whereby the body floated down the Columbia River and came to rest away from the main channel where it was subsequently buried by flood deposits. Evidence supporting this view includes a lack of grave goods and absence of other burials at the discovery site despite recurrent bank erosion prior to 1998. In contrast, Powell and Rose [17] and Walker et al. [22] believe that the skeleton was more likely placed in the ground by humans. In lieu of better stratigraphic contextual information, Walker et al. [22] conclude that the burial mechanism for Kennewick Man remains uncertain, but that rapid burial through "catastrophic hydrologic processes is exceedingly rare."

We concur that both human burial and rapid alluvial sedimentation are viable hypotheses. However, we interpret the sedimentology and stratigraphy of the discovery site as indicative of low-energy deposition with relatively small increments of vertical accretion. Sediments from the upper part of Unit 2 are predominantly finetextured, silty alluvium deposited in a low-energy backwater environment of the Columbia River floodplain $[11,21]$. Much of Unit 2 has been bioturbated, although in places there are preserved bedforms including thin horizontal laminae and trough crossbeds suggestive of climbing ripples [11]. It is not possible to discern discrete flood events within the stratigraphy and determine the amount of sediment deposited during individual floods. Well-dated, fine-textured Holocene overbank flood strata identified elsewhere on the Columbia River (e.g. Ref. [7]) are generally thin, commonly less than $25 \mathrm{~cm}$ thick. Thicker flood deposits are possible in backwater (flood basin) settings, but such rapid deposition is typically associated with large instantaneous discharges, rapid water velocities, and coarse (sand and gravel) textured deposits. The upper part of Unit 2 contains horizontally extensive layers of silt subjected to pedogenesis suggestive of slow vertical accretion. Consequently, we agree with Powell and Rose [17] and Walker et al. [22] that rapid burial of Kennewick Man was more likely accomplished by human placement of the body into the upper part of Unit 2. Further stratigraphic work at the discovery site would help test the two competing hypotheses by documenting deposit architecture and augmenting existing sedimentological and chronological data.

If the skeleton were interred, then most of the primary sediments in contact with the buried skeleton would have been layered deposits mixed as backfill for the grave. Hence, mixing of the terrace sediments by bioturbation, and mixing of the grave sediments by humans would itself complicate the matching of skeleton sediments to a particular depth based on primary features (e.g. grain size). Secondary features, such as concretions and secondary clay minerals would be more useful for correlation because they formed after burial. Moreover, because an interred body is intrusive into the underlying deposit, any radiocarbon date from an organic layer located at the same depth of the body would predate the death of the organism because it was actually from a lower stratum. How much it would predate the organism would depend on the rate of deposition. Presently, there is insufficient age control to determine accumulation rates for Unit 2.

The sedimentological analysis performed on the sediments associated with Kennewick Man was nondestructive to the bone and provided additional contextual information for the skeleton. During our investigation, there was only a single bone ${ }^{14} \mathrm{C}$ date, and our sedimentological correlations provided independent support for this age. Because the DOI based determination of Native American status for the skeleton on chronological criteria, i.e. any human remains predating AD 1492, the court would require high levels of confidence in any age determination. Consequently, the DOI elected to perform further ${ }^{14} \mathrm{C}$ dating and interpreted the results to support the approximately 9000 CAL yr age (Table 1). Sedimentological analyses such as these may prove useful in future NAGPRA related cases where nondestructive analyses are needed to help determine original provenience of human remains.

\section{Acknowledgements}

We thank Frank McManamon (DOI), Lillian Wakeley (ACE Waterways Experiment Station), and Sonny Trimble, Rhonda Lueck, and Teresa Militello (ACE) for their support. We also thank Vicki Cassman and Nancy Odegaard, conservators, for their help with extracting the sediment from bone, and Laura Phillips at the Burke Museum for help with the samples. Also helping us in our analyses were Brian Flinn and Kyle Flanigan (University of Washington) and Sandy Lilligren and Charles Knaack (Washington State University). We appreciate the helpful critical comments from an anonymous reviewer on an earlier version of this article. 
Appendix A. Trace element laboratory results

\begin{tabular}{|c|c|c|c|c|c|c|c|c|c|c|c|c|c|c|}
\hline \multicolumn{3}{|l|}{ Provenience } & $\mathrm{La}$ & $\mathrm{Ce}$ & $\operatorname{Pr}$ & $\mathrm{Nd}$ & $\mathrm{Sm}$ & $\mathrm{Eu}$ & $\mathrm{Gd}$ & $\mathrm{Tb}$ & Dy & Ho & $\mathrm{Er}$ & $\mathrm{Tm}$ \\
\hline \multicolumn{15}{|l|}{ Site sediments } \\
\hline СРP054, 10-20 cm & & & 29.38 & 55.60 & 6.83 & 26.03 & 5.51 & 1.27 & 4.57 & 0.71 & 3.92 & 0.77 & 2.13 & 0.32 \\
\hline CPP054, 30-40 cm & & & 35.79 & 66.40 & 8.05 & 30.11 & 6.24 & 1.43 & 5.05 & 0.79 & 4.35 & 0.84 & 2.35 & 0.35 \\
\hline СРP054, 50-60 cm & & & 34.08 & 62.27 & 7.55 & 27.90 & 5.71 & 1.28 & 4.69 & 0.71 & 3.84 & 0.74 & 2.11 & 0.31 \\
\hline CPP054, 70-80 cm & & & 34.39 & 63.12 & 7.63 & 28.33 & 5.62 & 1.29 & 4.60 & 0.69 & 3.74 & 0.73 & 2.00 & 0.30 \\
\hline СРP054, 80-90 cm & & & 35.37 & 65.26 & 7.89 & 29.09 & 5.91 & 1.32 & 4.58 & 0.72 & 3.69 & 0.72 & 1.97 & 0.29 \\
\hline СРP054, 95-135 cm & & & 32.93 & 61.25 & 7.43 & 27.98 & 5.74 & 1.34 & 4.67 & 0.71 & 3.81 & 0.75 & 2.08 & 0.30 \\
\hline $\mathrm{CPC} 059.5,0-10 \mathrm{~cm}$ & & & 33.56 & 60.51 & 7.16 & 26.80 & 5.37 & 1.31 & 4.68 & 0.72 & 3.66 & 0.72 & 2.02 & 0.30 \\
\hline $\mathrm{CPC} 059.5,30-40 \mathrm{~cm}$ & & & 36.12 & 66.06 & 7.80 & 28.80 & 5.69 & 1.40 & 4.99 & 0.76 & 3.83 & 0.74 & 2.00 & 0.30 \\
\hline СРC059.5, 60-66 cm & & & 36.16 & 66.68 & 8.05 & 30.06 & 5.89 & 1.39 & 4.81 & 0.75 & 4.07 & 0.78 & 2.18 & 0.32 \\
\hline CPC060 (concretions), $0-10 \mathrm{~cm}$ & & & 22.12 & 36.43 & 4.84 & 18.33 & 3.84 & 0.92 & 3.51 & 0.59 & 3.43 & 0.72 & 2.13 & 0.32 \\
\hline \multicolumn{15}{|l|}{ Skeletal sediments } \\
\hline I.25.C (exterior concretion) & & & 16.99 & 31.09 & 3.87 & 14.07 & 2.92 & 0.71 & 2.49 & 0.39 & 2.08 & 0.41 & 1.17 & 0.17 \\
\hline L.24(Mta+Mtb) & & & 33.45 & 60.24 & 7.29 & 26.96 & 5.41 & 1.26 & 4.54 & 0.70 & 3.60 & 0.69 & 1.93 & 0.28 \\
\hline U.1.a (friable peds) & & & 29.44 & 54.13 & 6.55 & 24.63 & 4.96 & 1.23 & 4.37 & 0.66 & 3.46 & 0.68 & 1.91 & 0.28 \\
\hline A.I.17a (dark sediment) & & & 32.47 & 59.70 & 7.24 & 27.46 & 5.57 & 1.37 & 4.75 & 0.73 & 3.79 & 0.74 & 2.00 & 0.31 \\
\hline R.13b+U.7b+A.I.17a & & & 20.69 & 38.35 & 4.54 & 16.71 & 3.31 & 0.82 & 2.96 & 0.46 & 2.43 & 0.48 & 1.37 & 0.21 \\
\hline R.18a & & & 29.19 & 52.69 & 6.42 & 23.61 & 4.66 & 1.14 & 4.02 & 0.61 & 3.29 & 0.61 & 1.63 & 0.24 \\
\hline Provenience & $\mathrm{Yb}$ & $\mathrm{Lu}$ & $\mathrm{Ba}$ & $\mathrm{Th}$ & $\mathrm{Nb}$ & $\mathrm{Y}$ & $\mathrm{Hf}$ & $\mathrm{Ta}$ & $\mathrm{U}$ & $\mathrm{Pb}$ & $\mathrm{Rb}$ & Cs & $\mathrm{Sr}$ & $\mathrm{Sc}$ \\
\hline \multicolumn{15}{|l|}{ Site sediments } \\
\hline $\mathrm{CPP} 054,10-20 \mathrm{~cm}$ & 2.05 & 0.32 & 664 & 6.74 & 13.85 & 21.86 & 2.20 & 0.86 & 1.87 & 11.38 & 63.7 & 2.47 & 398 & 16.3 \\
\hline CPP054, 30-40 cm & 2.33 & 0.36 & 770 & 8.22 & 15.90 & 24.08 & 2.54 & 0.96 & 2.11 & 12.68 & 70.2 & 2.73 & 458 & 16.9 \\
\hline CPP054, 50-60 cm & 2.00 & 0.32 & 716 & 7.34 & 14.67 & 21.60 & 2.15 & 0.91 & 1.52 & 12.25 & 66.6 & 2.74 & 404 & 15.0 \\
\hline CPP054, 70-80 cm & 1.96 & 0.31 & 753 & 7.28 & 15.12 & 21.26 & 2.14 & 0.91 & 1.46 & 12.79 & 70.6 & 2.77 & 406 & 14.7 \\
\hline СРP054, 80-90 cm & 1.90 & 0.29 & 759 & 7.31 & 15.00 & 21.28 & 1.97 & 0.89 & 1.46 & 12.61 & 71.1 & 2.70 & 407 & 14.7 \\
\hline CPP054, $95-135 \mathrm{~cm}$ & 2.01 & 0.32 & 729 & 6.97 & 15.86 & 21.90 & 2.17 & 0.99 & 1.37 & 12.98 & 69.7 & 2.82 & 401 & 15.9 \\
\hline СРC059.5, 0-10 cm & 1.90 & 0.31 & 747 & 6.03 & 14.86 & 23.46 & 2.02 & 0.85 & 1.38 & 16.49 & 70.4 & 2.52 & 452 & 15.3 \\
\hline СРC059.5, 30-40 cm & 1.98 & 0.31 & 777 & 6.8 & 16.37 & 23.91 & 2.12 & 0.92 & 1.27 & 13.31 & 76.7 & 2.85 & 428 & 16.5 \\
\hline СРC059.5, 60-66 cm & 2.09 & 0.33 & 756 & 7.24 & 15.40 & 22.46 & 2.37 & 1.00 & 1.39 & 13.70 & 70.8 & 2.86 & 403 & 15.9 \\
\hline CPC060 (concretions), $0-10 \mathrm{~cm}$ & 2.13 & 0.37 & 472 & 4.29 & 7.93 & 22.70 & 1.23 & 0.48 & 2.30 & 7.47 & 37.0 & 1.48 & 507 & 7.5 \\
\hline \multicolumn{15}{|l|}{ Skeleton sediments } \\
\hline I.25.C (exterior concretion) & 1.12 & 0.18 & 450 & 3.36 & 7.41 & 11.87 & 1.22 & 0.45 & 4.21 & 5.75 & 33.3 & 1.37 & 514 & 7.4 \\
\hline L.24(Mta+Mtb) & 1.82 & 0.29 & 684 & 6.30 & 14.82 & 21.05 & 1.97 & 0.88 & 2.02 & 10.52 & 61.1 & 2.23 & 508 & 14.6 \\
\hline U.1.a (friable peds) & 1.81 & 0.29 & 652 & 5.71 & 13.19 & 21.26 & 2.03 & 0.77 & 1.79 & 10.22 & 61.5 & 2.34 & 455 & 14.7 \\
\hline A.I.17a (dark sediment) & 1.95 & 0.31 & 691 & 6.03 & 14.21 & 112.84 & 2.20 & 0.83 & 2.74 & 15.05 & 64.3 & 2.48 & 418 & 15.9 \\
\hline R.13b+U.7b+A.I.17a & 1.35 & 0.22 & 459 & 3.78 & 8.29 & 15.42 & 1.27 & 0.49 & 3.75 & 6.41 & 37.0 & 1.44 & 588 & 8.5 \\
\hline R.18a & 1.58 & 0.25 & 615 & 5.47 & 13.17 & 18.61 & 1.88 & 0.75 & 1.54 & 9.94 & 60.2 & 2.22 & 442 & 13.7 \\
\hline
\end{tabular}

Data presented in parts per million. Analyzed with an inductively coupled plasma source mass spectrometer at the Washington State University Geoanalytical Laboratory using a Sciex Elan Model 250 with a Babington nebulizer, water-cooled spray chamber, and Brooks mass flow controllers. Sediments were ground into a fine powder and dissolved in hydrofluoric, nitric, and perchloric acids. Resulting solutions and control samples were ionized at $7000{ }^{\circ} \mathrm{C}$.

\section{References}

[1] V.R. Baker, D. Nummedal, The Channeled Scabland, National Aeronautics and Space Administration, Washington, DC, 1978.

[2] J.H. Bretz, The Lake Missoula floods and the Channeled Scabland, Journal of Geology 77 (1969) 505-543.

[3] P. Bullock, N. Fedoroff, A. Jongerius, G. Stoops, T. Tursina, U. Babel, Handbook for Soil Thin Section Description, Waine Research, Wolverhampton, 1985.

[4] A. Chappel, Dispersing sandy soil for the measurement of particle-size distributions using optical laser diffraction, Catena 31 (1998) 271-281.

[5] J. Chatters, The recovery and first analysis of an early Holocene human skeleton from Kennewick, Washington, American Antiquity 65 (2) (2000) 291-316.

[6] J. Chatters, Ancient Encounters: Kennewick Man and the First Americans, Simon and Schuster, New York, 2001.
[7] J. Chatters, K. Hoover, Changing late Holocene flooding frequencies on the Columbia River, Washington, Quaternary Research 26 (1986) 309-320.

[8] J. Chatters, K. Hoover, Response of the Columbia River fluvial system to Holocene climate change, Quaternary Research 37 (1992) 42-59.

[9] M.A. Courty, P. Goldberg, R.I. Macphail, Soils and Micromorphology in Archaeology, Cambridge University Press, Cambridge, 1989.

[10] H. Hammatt, Late Quaternary Stratigraphy and Archaeological Chronology in the Lower Granite Reservoir Area, Lower Snake River, Washington, PhD Thesis, Washington State University, 1977.

[11] G. Huckleberry, T.W. Stafford Jr., J. Chatters, Preliminary Geoarchaeological Studies at Columbia Park, Kennewick, Washington, USA, Report on File with US Army Corps of Engineers, Walla Walla District, Washington, 1998. 
[12] G. Huckleberry, C. Gustafson, S. Gibson, Stratigraphy and site formation processes, in: B.A. Hicks (Ed.), Marmes Rockshelter (45FR50): Preliminary Report, Confederated Tribes of the Colville Reservation, Nespelem, 1998, pp. 44-98.

[13] V. Morell, Kennewick Man: more bones to pick, Science 279 (1998) 25-26.

[14] V. Morell, Kennewick Man's trials continue, Science 280 (1998) 190-192.

[15] R.C. Murray, J.C.F. Tedrow, Forensic Geology, Prentice Hall, Englewood Cliffs, 1992.

[16] J. O'Connor, R. Waitt, D. Johnston, Beyond the Channeled Scabland: a field trip to Missoula flood features in the Columbia, Yakima, and Walla Walla Valleys of Washington and Oregon-Part 1, Oregon Geology 57 (1995) 51-60.

[17] J. Powell, J. Rose, Report on the Osteological Assessment of the "Kennewick Man" Skeleton (CENWW.97.Kennewick) http://www.cr.nps.gov/aad/kennewick (1999).

[18] S. Reidel, K. Fecht, Geologic Map of the Rich Land 1:100,000 Quadrangle, Washington, Washington Division of Geology and Earth Resources, Open File Report 94-8, Olympia, WA, 1994.

[19] J.K. Stein, Organic matter in archaeological contexts, in: V. Holliday (Ed.), Soils in Archaeology: Landscape Evolution and
Human Occupation, Smithsonian Institution Press, Washington, DC, 1992, pp. 193-216.

[20] R. Taylor, D. Kirner, J. Southon, J. Chatters, Radiocarbon dates of Kennewick Man, Science 280 (1998) 1171-1172.

[21] L. Wakeley, W. Murphy, J. Dunbar, A. Warne, F. Briuer, Geologic, Geoarchaeologic, and Historical Investigation of the Discovery Site of Ancient Remains in Columbia Park, Kennewick, Washington, US Army Corps of Engineers, Waterways Experiment Station Technical Report GL-98-13, Vicksburg, MS, 1998.

[22] P.L. Walker, C.S. Larsen, J.F. Powell, Final report on the physical examination and taphonomic assessment of the Kennewick human remains http://www.cr.nps.gov/aad/kennewick (2000).

[23] C.M. Zdanowicz, G.A. Zielinski, M.S. Germani, Mount Mazama eruption: calendrical age verified and atmospheric impact assessed, Geology 27 (1999) 621-624.

[24] E. McDonald, A. Busacca, Late Quaternary stratigraphy of loess in the Channeled Scabland and Palouse regions of Washington state, Quaternary Research 38 (1992) 141-156.

[25] G. Huckleberry, J. Stein, Analysis of sediments associated with human remains found at Columbia Park, Kennewick, WA http:// www.cr.nps.gov/aad/design/kennewick/kennewick.htm (1999). 